\title{
Genetic variability of some vegetative and flowering growth characteristics of multiflower mutant of Helianthus annuus L. plants
}

\author{
Gehan G. Mostafa \\ Department of Horticulture (Ornamental Plants), Faculty of Agriculture, Beni Suef University, Egypt \\ Corresponding auther: E mail : gehangaber2006@yahoo.com
}

Received on: 29/4/2020

Accepted on: 21/5/2020

\begin{abstract}
Present investigation was conducted to study the genetic variability of some growth and flowering traits of branching mutant of Helianthus annuus (sunflower) plants that having many inflorescences per plant. This s tudy was done during two successive seasons at the Nursery of Ornamental Plants, Faculty of Agriculture, South Valley University, Qena, Egypt.

High broad sense heritability with high genetic variance( GCV\% and PCV\%) were found for number of inflorescences per plant, stem diameter, leave area, fresh weight of vegetative growth and 100 seeds weight. This result refer to the small amount of environmental effects and these traits are under the influence of genetic control. While high heritability in broad sense with moderate genetic variance were found for plant height. Whereas moderate heritab ility in broad sense with moderate genetic variance were found for number of leaves per plant, inflorescence diameter, number of seeds per mean head. So, Selection is an expected tool to improve branching mutant of Helianthus annuus plant characteristics.
\end{abstract}

KEYWORDS: heritability, Selection, phenotypic coefficient of variation, genotypic coefficient of variation, Helianthus annuus

\section{INTRODUCTION}

Helianthus annuus plants is belongs to family Asterace. They are commercially grown for different uses: inflorescences as cut flowers, seeds for feed birds, oil extracted from the seeds are used for cooking.

Selection is the most important process which alter the frequencies gene of population

(Gvozdenovic et al., 2009) which may be greater or lesser than the population mean

Selection methods is effective only in the presence of large variability in the population. Consequently, genetic variability is the prerequisite for an effective breeding programme in many crops and it differs from one to other due to its evolutionary process and complexity of genetic system (Datta, 2012).

The variation in a segregating population is divided to both genotypic variance and phenotypic variance Powers (1957) and Panse (1957) further partitioned the genotypic variance into additive and non-additive components. The non-additive one includes dominance and inter allelic interactions. The additive component of genetic variance is highly heritable and the characters are fixable through selection resulting in maximum genetic advance

Improvement of high quality plants requires a knowledge about genetic variation. Genetic improvement of any plant is dependent on the degree of the genetic parameters such as: phenotypic and genotypic variances, phenotypic and genotypic coefficient of variation (PCV and GCV), broad sense heritability and genetic gain; on which the breeding methods are formulated for its further improvement Roychowdhury and Tah (2011).

Therefore, present investigation was conducted to study genetic variability of some growth and flowering traits of branching mutant of sunflower plants that having many inflorescences per plant.

\section{MATERIALS AND METHODS}

The study was investigated at the Nursery of Ornamental Plants, Faculty of Agriculture, South Valley University, Qena, Egypt from 2011 to 2015.

The branching mutant of Helianthus annuus that have many inflorescences/ plant was used in this study that obtained from previous study (Mostafa, 2011). The mutant was achieved from previous study using cv. Giza 102 treated with 100 ppm sodium azide in the $\mathrm{M}_{2}$ generation (2). Seeds of the selected mutant as a base population were sown in the field on May 2011 in a non-replicated area. The procedure of three cycles of mass selection was done. After that seeds of unbranched parent (cv. Giza 102), base population (branched mutant), and three cycles of mass selection were sown on 15 May 2014 and 2015, to estimate the genetic parameters. 


\subsection{Recorded data}

At flowering stage: plant height $(\mathrm{cm})$, number of leaves, stem diameter $(\mathrm{cm})$, leaf area $\left(\mathrm{cm}^{2}\right)$, fresh weight of vegetative growth $(\mathrm{g})$, flow ering date (days from sowing seeds to showing color of the first inflorescence per plant), number of inflorescences per plant, number of ray florets per inflorescence and inflorescence diameter $(\mathrm{cm})$ were recorded. Chlorophyll content (SPAD unit) was estimated as described by Yadava (1986). Number of seeds per main head and twenty seeds weight were recorded at the maturity stage.

\subsection{Statistical analysis}

Data were statistically analyzed using analysis of variance for randomized complete block design (RCBD) for separate analysis as Gomez and Gomez (1984). Moreover, genetic parameters were estimated as follow:

Genotypic variance $\delta^{2} \mathrm{~g}=(M S G-M S E) / r$

Where MSG is mean square of genotype,MSE is mean square of the error, and $r$ is number of replications.

Phenotypic variance $\delta^{2} \mathrm{p}=\delta^{2} \mathrm{~g}+\delta^{2} \mathrm{e}$

Where $\delta^{2}$ is genotypic variance and $\delta^{2}$ is the mean square of error

The estimate of phenotypic and genotypic coefficient of variation (PCV\%) and (GCV\%) were calculated according to Singh and Choudhary(1985) as follow:

$\mathrm{PCV} \%=\left(\frac{\sqrt{\delta 2 \mathrm{p}}}{\mathrm{X}}\right) \mathrm{X} 100, \mathrm{GCV} \%=\frac{\sqrt{\delta 2 \mathrm{~g}}}{X} \mathrm{X} 100$

Where $\mathrm{X}$ is the mean of the trait. GCV\% and PCV\% values were categorized as low $(0-10 \%)$, moderate (10-20\%) and high (20\% and above) as described by Sivasubra manian and Madhava Menon (1973).

Heritability in broad sense was calculated according to Falconer 1989 as follow s: $h^{2} B=\delta 2 g / \delta 2 p$

The heritability percentage was categorized as follow $(0-30 \%)$, moderate $(30-60 \%)$, and high ( $\geq 60 \%$ ) as described by Robinson et al. 1949

Predicted genetic advance GA\% was calculated using the method of Oladosu et al., 2014 as follow:

$\mathrm{GA} \%=\mathrm{K} \times \sqrt{\delta 2 \mathrm{p} /} X \times \mathrm{h}^{2} \mathrm{Bx} 100$, where $\mathrm{K}$ is selection intensity which assumed $5 \%$ and its value is 2.06 . It was categorized as low $(0-10 \%)$, moderate (10-20\%), and high $(\geq 20 \%)$

\section{RESULTS}

The genotypic and phenotypic variance expressed as GCV\% and PCV\% were moderate for plant height (10.61 and 13.45 for $1^{\text {st }}$ season and 10.29 and 12.93 for $2^{\text {nd }}$ season respectively) as shown in Table 1. Heritability in broad sense was high (62 and 63 for $1^{\text {st }}$ and $2^{\text {nd }}$ seasons respectively)

For stem diameter, GCV percentage and PCV percentage were high for both seasons $(24.03,25.1$ for $1^{\text {st }}$ season, 26.4 and 24.7 for $2^{\text {nd }}$ season). High heritability also found ( 0.91 and 92.0 for both season respectively)

Genotypic coefficient of variance for number of leaves per plant was ranged between low to moderate value $\left(8.20,18.04\right.$ in the $1^{\text {st }}$ and $2^{\text {nd }}$ seasons respectively). While phenotypic coefficient of variance-possessed moderate to high values (11.03, 20.7 for $1^{\text {st }}$ and $2^{\text {nd }}$ seasons respectively). Heritability in broad sense was moderate 0.55 in the $1^{\text {st }}$ season but seems to be high (75) for $2^{\text {nd }}$ season.

Leaf area possess a high phenotypic and genotypic variance in both seasons $\left(46.96,43.6\right.$ for $1^{\text {st }}$ seas on and 45.59 and 37.63 in the $2^{\text {nd }}$ season). Also high heritability was found in both seasons (91 and 68 for $1^{\text {st }}$ and $2^{\text {nd }}$ seasons respectively

High genotypic and phenotypic variances were found with respect of fresh weight of vegetative growth coupled with high heritability value in both seasons.

Low PCV\% and GCV\% values were found for chlorophyll content traits $\left(9.47,7.46\right.$ in the $1^{\text {st }}$ season and 10.33 and 7.95 in the $2^{\text {nd }}$ one). Heritability in broad sense ranged from moderate $\left(0.59\right.$ in the $2^{\text {nd }}$ season) to high ( 0.62 in the $1^{\text {st }}$ season)

Number of inflorescences per plant presents high values of PCV\%, GCV\% and heritability in broad sense $\left(25.08,24.41,0.94\right.$ in the $1^{\text {st }}$ season and 25.5, 21.54 and 71 for $2^{\text {nd }}$ season respectively).

Low phenotypic and genotypic variances were found in number of ray floret/ inflorescence, while a moderate heritability values were found in both seasons.

Regards inflorescence diameter, moderate phenotypic and genotypic variance were found $\left(15.99,11.90\right.$ in the $1^{\text {st }}$ season and 15.80 and 14.92 in the $2^{\text {nd }}$ season). At the same line, high heritability was found (89) in the $2^{\text {nd }}$ season.

Moderate PCV\%, GCV\% and heritability values were found with respect to number of seed per mean head in both seasons.

On the other hand, high PCV\%, GCV\% and heritability were found for 100 seeds weight traits $\left(30.14,28.48\right.$ and 89 in the $1^{\text {st }}$ season and 30.94, 30.44 and 96 in the $2^{\text {nd }}$ seasons. Predicted genetic advance (GA \%) was found to be moderate to high values in most cases in both seasons

\section{DISCUSSION}

Study the genetic variability of some growth and flowering traits of branching mutant of sunflower plants that having many inflorescences per plant. Because that the knowledge about PCV\%, GCV\% and Heritability enables the plant breeder to decide the method of selection procedure. 


\section{Gehan G. Mostafa, 2020}

Table 1. Genetic estimates for Plant height $(\mathrm{cm})$, Stem diameter $\left(\mathrm{cm}^{2}\right)$, No. of leaves, Leaf area $\left(\mathrm{cm}^{2}\right)$, Fresh weight of vegetative growth (gm), Chloroph yll content (SPAD unit), No.of inflorescence, No. of ray florets, Inflorescence diameter $(\mathrm{cm})$, No. of seeds/me an head, $100 \mathrm{seeds}$ weight $(\mathrm{gm})$ for multiflower mutant of Helianthus annuus L. plants during two seasons.

\begin{tabular}{|c|c|c|c|c|c|c|c|c|c|c|c|}
\hline $\begin{array}{c}\text { Genetic } \\
\text { parameters }\end{array}$ & $\begin{array}{l}\text { Plant } \\
\text { height } \\
(\mathrm{cm})\end{array}$ & $\begin{array}{c}\text { Stem } \\
\text { diameter } \\
\left(\mathrm{cm}^{2}\right)\end{array}$ & $\begin{array}{l}\text { No. of } \\
\text { leaves }\end{array}$ & $\begin{array}{l}\text { Leaf } \\
\text { area } \\
\left(\mathrm{cm}^{2}\right)\end{array}$ & $\begin{array}{l}\text { Fresh weight } \\
\text { of vegetative } \\
\text { growth }(\mathrm{gm})\end{array}$ & $\begin{array}{l}\text { Chlorophyll } \\
\text { content } \\
\text { (SPAD unit) }\end{array}$ & $\begin{array}{c}\text { No.of } \\
\text { inflorescence }\end{array}$ & $\begin{array}{l}\text { No. of } \\
\text { ray } \\
\text { florets }\end{array}$ & $\begin{array}{l}\text { Inflorescence } \\
\text { diameter }(\mathbf{c m})\end{array}$ & $\begin{array}{l}\text { No. of } \\
\text { seeds/mean } \\
\text { head }\end{array}$ & $\begin{array}{c}\text { 100seeds } \\
\text { weight } \\
\text { (gm) }\end{array}$ \\
\hline \multicolumn{12}{|c|}{ First season } \\
\hline$\delta^{2} \mathbf{g}$ & 246.05 & 0.11 & 6.61 & 11594.2 & 14488.5 & 4.49 & 15.6 & 2.47 & 0.48 & 1718.29 & 1.19 \\
\hline$\delta^{2} p$ & 395.45 & 0.12 & 11.96 & 13448.3 & 15917.28 & 7.23 & 16.48 & 5.89 & 0.86 & 3465.73 & 1.33 \\
\hline PCV\% & 13.45 & 25.10 & 11.03 & 46.96 & 38.86 & 9.47 & 25.08 & 6.05 & 15.99 & 13.73 & 30.14 \\
\hline GCV\% & 10.61 & 24.03 & 8.20 & 43.60 & 37.07 & 7.46 & 24.41 & 3.91 & 11.90 & 9.66 & 28.48 \\
\hline $\mathbf{h}^{2} \mathbf{B}$ & 0.62 & 0.91 & 0.55 & 0.86 & 0.91 & 0.62 & 0.94 & 0.41 & 0.55 & 0.49 & 0.89 \\
\hline GA\% & 17.17 & 0.64 & 12.50 & 83.2 & 72.85 & 12.10 & 48.5 & 5.10 & 18.0 & 13.86 & 55.2 \\
\hline \multicolumn{12}{|c|}{ Second season } \\
\hline$\delta^{2} \mathbf{g}$ & 206.25 & 0.12 & 37.08 & 6527.43 & 14952.51 & 8.47 & 16.06 & 3.47 & 0.77 & 2989.23 & 0.92 \\
\hline$\delta^{2} \mathbf{p}$ & 325.31 & 0.13 & 48.82 & 9581.4 & 16798.33 & 14.29 & 22.50 & 10.94 & 0.86 & 5179.38 & 0.95 \\
\hline PCV & 12.93 & 26.4 & 20.70 & 45.59 & 38.46 & 10.33 & 25.50 & 8.19 & 15.80 & 18.26 & 30.94 \\
\hline GCV & 10.29 & 24.7 & 18.04 & 37.63 & 36.28 & 7.95 & 21.54 & 4.61 & 14.92 & 13.87 & 30.44 \\
\hline $\mathbf{h}^{2} \mathbf{B}$ & 0.63 & 0.92 & 0.75 & 0.63 & 0.89 & 0.59 & 0.71 & 0.31 & 0.89 & 0.57 & 0.96 \\
\hline GA\% & 16.78 & 0.65 & 31.99 & 63.87 & 70.51 & 12.56 & 37.29 & 5.23 & 28.91 & 21.44 & 61.19 \\
\hline
\end{tabular}

$\boldsymbol{\sigma}^{2} \mathbf{P}$ : phenotypic variances; $\boldsymbol{\sigma}^{2} \mathbf{G}$ : Genotypic variances; PCV\%: Phenotypic coefficient of variance; GCV\%: Genotypic coefficient of variance; ${ }^{2} \mathrm{~B}$ : Heritability; GA\%: predicted genetic advance. 
High broad sense heritability with high genetic variance for most studied traits were found. This result refer to the small amount of environmental effects and these traits are under the influence of genetic control (Natikar et al., 2013). Therefore, this result suggested the greater effectiveness of selection as expected tool to improve Helianthus annuus plant characteristic $s$

These results are in the line with the finding of Roychowdhury and Tah (2011), Mostafa (2016), Mohamed et al.(2019)

\section{Conclusion}

Selection is an expected tool to improve branching mutant of Helianthus annuus plant characteristics

\section{References}

Datta SK (2012). Success story of induced mutagenesis for development of new ornamental varieties. Biodiversity and Bioavailability. 6(1): 1526.

Falconer DS (1989). Introduction to quantitative genetics (3rd Edn.), ELBS England, Pp. 1-340.

Gomez KA and Gomez AA (1984) Statistical procedures for agriculture research. 2nd Edn., John Wiley and Sons, New York, USA., ISBN13:9780471870920, page: 680 .

Gvozdenovic S, Bado S, Afza R, Jocic S, Mba C (2009). Intervarietal differences in response of sunflower (Helianthus annuus L.) to different mutagenic treatments. In: Induced plant mutations in the genomics Era,Hu.Q.Y.(Eds.) Food and Agriculture Organization of the United Nations, Rome,pp:358-360.

Mohamed MA, Aly MK, Mostafa GG, Abd Alaziz HR (2019) Evaluation of chrysanthemum morifolium cv. Maghi plants after sodium azide treatment. Scientific Journal of Agricultural Sciences 1(1):14-20.

Mostafa GG (2011) Effect of sodium azide on the growth and variability induction in Helianthus annuus L. International journal of plant breeding and genetics. 5(1):76-85.

Mostafa GG (2016) Improvement the branching mutant of Helianthus annuus by mass selection. Asian Journal of crop Sciences 8: 60-65.

Natikar P, Madhusudan K, Kage U, Nadaf HI, Motagi BN (2013) Genetic variability studies in induced mutants of sunflower(Helianthus annuus L.). Plant Gene and Trait 4(16): 86-89

Oladosu Y, Rafii MY, Abdullah N, Abdul-Malek M, Rahim HA, Hussin G, Abdullatif M, Kareem I (2014). Genetic variability and selection criteria in Rice mutant lin Genetices as revealed by quantitative traits.The scientific World Journal 2014(190531),1-12.

https://doi.org/10.1155/2014/190531

Panse VG, Sukhatme PV (1967). Statistical methods for agricultural workers (2nd Ed.). ICAR public ation, New Delhi. 381 p,

Powers L (1957). The nature of the series of environmental variances and the estimation of genetic variances and the geometric means of crosses involving species of Lycopersicum. J. Genetics, 27: 561-575.

Robinson HF, Johnson HW, Comstock RE (1949). Estimates of genetic and environmental variability in soybean. J.Agronomy, 17:28-36.

Roychowdhury R, Tah J (2011). Chemical mutagenic action on seed germination and related agro-metrical traits in M1 Dianthus generation. Current. Botany, 2: 19-23.

Singh RK, Chaudhary BD (1985). Biometrical methods in quantitative genetic analysis. Kalyani Publishers, Ludhiana. 318 p.

Sivasubramanian S, Menon M(1973). Heteros is and inbreeding depression in rice Madras Agriculture J.,60:274-277.

Yadava $L$ (1986) A rapid and non-destruction method to determine chlorophyll in intact leaves. Hort Science. 21:1449-1450. 
Gehan G. Mostafa, 2020

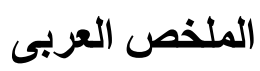

التباين الوراثي لبعض صفات النمو الخضرى و الزهرى لطفرة نبات عباد الشمس متعدة النورات

جيهان جابر مصطفى

قسم البساتين(زهور و زينة)، كلية الزر اعة، جامعة بنى سويف

تم إجراء البحث الحالي لدراسة التباين الوراثي لبعض صفات النمو والإزهار لطفرة متعددة الازهار لنباتات عباد الثمس والتي تحتوي على الثى

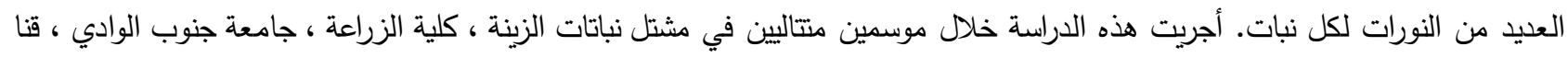
، مصر.

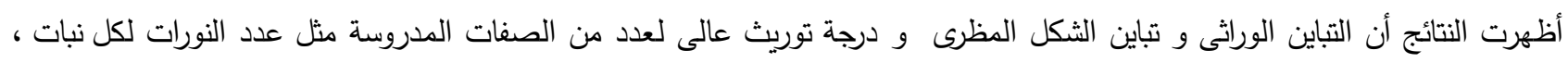

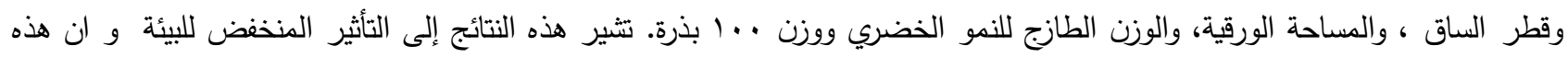
الصفات متحكم فيها وراثيا

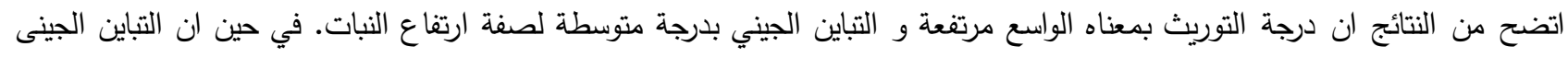

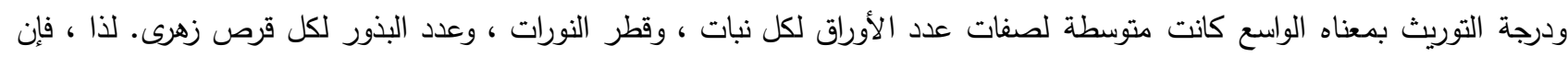
الانتخاب هو وسيلة فعالة متوقعة لتحسين نمو نبات Helianthus annuus ذو الازهار المتعددة 